\title{
Heavy metals contamination and associated health risks in food webs - a review focuses on food safety and environmental sustainability in Bangladesh
}

\author{
Aniruddha Sarker ${ }^{1,6} \cdot$ Jang-Eok Kim $^{1} \cdot$ Abu Reza Md. Towfiqul Islam ${ }^{2} \cdot$ Muhammad Bilal $^{3} \cdot$ Md. Refat Jahan Rakib $^{4}$. \\ Rakhi Nandi $^{1,7} \cdot$ Mohammed M. Rahman ${ }^{8} \cdot$ Tofazzal Islam $^{5}$ (I)
}

Received: 23 July 2021 / Accepted: 18 October 2021 / Published online: 5 November 2021

(c) The Author(s), under exclusive licence to Springer-Verlag GmbH Germany, part of Springer Nature 2021

\begin{abstract}
Heavy metals occur naturally in very small amounts in living organisms, but exposure to their higher concentrations is hazardous. Heavy metals at hazardous levels are commonly found in foodstuffs of Bangladesh, mainly due to the lack of safety guidelines and poor management of industrial effluents. Several lines of evidence suggest that the level of heavy metals in foodstuffs of Bangladesh is higher than the acceptable limits set by World Health Organization/Food and Agriculture Organization. Literature survey revealed that the sources and transport pathways of heavy metals in the ecosystem and the abundance of heavy metals in the food products of Bangladesh are potential threats to food safety. However, an extensive assessment of the toxicity of heavy metals in food webs is lacking. Although widespread heavy metal contamination in various foodstuffs and environmental matrices have been summarized in some reports, a critical evaluation regarding multi-trophic transfer and the health risk of heavy metal exposure through food chain toxicity in Bangladesh has not been performed. This systematic review critically discussed heavy metal contamination, exposure toxicity, research gaps, existing legislation, and sustainable remediation strategies to enhance Bangladesh's food safety. In particular, this study for the first time explored the potential multi-trophic transfer of heavy metals via food webs in Bangladesh. Furthermore, we recommended a conceptual policy framework to combat heavy metal contaminations in Bangladesh.
\end{abstract}

Keywords Heavy metals $\cdot$ Food safety $\cdot$ Risk assessment $\cdot$ Exposure toxicity $\cdot$ Policy framework

\section{Introduction}

Aniruddha Sarker and Jang-Eok Kim contributed equally to this paper.

Responsible Editor: Philippe Garrigues

Tofazzal Islam

tofazzalislam@bsmrau.edu.bd

1 School of Applied Biosciences, College of Agriculture and Life Sciences, Kyungpook National University, Daegu 41566, Republic of Korea

2 Department of Disaster Management, Begum Rokeya University, Rangpur 5400, Bangladesh

3 School of Life Science and Food Engineering, Huaiyin Institute of Technology, Huaian, China

4 Department of Fisheries and Marine Science, Faculty of Science, Noakhali Science and Technology University, Noakhali, Bangladesh
Heavy metals such as arsenic, lead, cadmium, and chromium are non-biodegradable hazardous substances derived from natural mineral sources or industrial discharges (Qin et al. 2020). The abundance of heavy metals in common foods,

5 Institute of Biotechnology and Genetic Engineering (IBGE), Bangabandhu Sheikh Mujibur Rahman Agricultural University, Gazipur, Bangladesh

6 Department of Soil Science, EXIM Bank Agricultural University Bangladesh (EBAUB), Chapainawabganj, Bangladesh

7 Bangladesh Academy for Rural Development (BARD), Kotbari, Cumilla, Bangladesh

8 Department of Chemistry, King Abdulaziz University, Jeddah 21589, Saudi Arabia 
such as fresh vegetables and fruits, poses several human health risks including carcinogenesis, kidney dysfunction, immune system imbalance, and even death due to biomagnification and bioaccumulation (Islam et al. 2015a; Ahmed et al. 2019a; Shamsudduha et al. 2019). Heavy metals are the predominant contaminants in most ecosystems of Bangladesh including agricultural land, foodstuffs, suburban soil, and waterways (Ahmed et al. 2015a; Kibria et al. 2016; Proshad et al. 2020; Hasan et al. 2021). The presence of heavy metals in common agricultural products, including rice, vegetables, fruits, and fish, has been reported (Ahmed et al. 2019a). In addition, the World Health Organization (WHO) has already expressed concern about the presence of trace metals (arsenic, lead, cadmium, and chromium) in drinking water and their contamination in the ecosystems in many countries, including Bangladesh (WHO 2004, 2017). Consequently, heavy metal contamination in the drinking water of the Surma basin of Bangladesh, and coastal groundwater were reported with a potential risk prediction including carcinogenic and non-carcinogenic risks to adults and children (Ahmed et al. 2019b; Islam et al. 2020a). Therefore, common foodstuffs, food chains, and water samples (e.g., river water and groundwater) were considered the critical source and sink of heavy metals in Bangladesh.

Heavy metals have also been recently detected in major food items, such as rice, vegetables, and meat available in large markets of Bangladesh (Proshad et al. 2020; Zakir et al. 2020a). A large body of literature indicates that arsenic, zinc, cadmium, copper, chromium, and lead are present at higher concentrations than the maximum tolerable limits (MTLs) set by WHO (Islam et al. 2015a; Islam et al. 2018a). Heavy metal contamination has been attributed to the poor management of industrial effluents, improper application of metal-rich irrigation water, improper handling of trace metal additives to poultry and fish feed, and rigorous application of heavy metal-containing pesticides and fertilizers, which lead to high toxicity levels and further transfer of heavy metals into the food chain (Pourang and Noori 2012; Sarker et al. 2017; Zakir et al. 2020b).

Weak monitoring of entry routes, poor understanding of safety measurements, ignorance of regulatory guidelines, and poor management of industrial effluents are the major causes of environmental and food contamination by hazardous heavy metals in Bangladesh (Shamsudduha et al. 2019; Zakir et al. 2020a). However, regulatory weaknesses related to heavy metal contamination are not considered a priority in research in Bangladesh. Although a few reviews have discussed the occurrence and toxicity profile of heavy metals in the food chain, soil, water, and environment of Bangladesh (Hezbullah et al. 2016; Islam et al. 2018a), the key challenges with respect to risk factors, legislation, and research gaps have been poorly explored. Heavy metal contamination and related biogeochemistry are a vast research area with respect to exposure and health risks throughout the world. Furthermore, heavy metal contamination, exposure toxicity, research gaps, existing legislation, and remediation for increasing food safety in Bangladesh are rarely assessed in the existing literature. Therefore, we planned to use this broad research theme to focus the current review on the existing challenges of heavy metal contamination in the food webs of Bangladesh for reducing the potential redundancies of the well-known concept of a satisfactory research theme in the environmental pollution. This review attempts to update current knowledge and critically discusses research trends and risk factors of heavy metal contamination in Bangladesh to facilitate safety and quality evaluations of the domestic food chain and the associated health risks. Furthermore, this study also discusses the critical challenges of heavy metal toxicity through multi-trophic transfer and recommends a conceptual policy framework in Bangladesh for sustainable remediation of heavy metals contamination.

\section{Review methodology}

This study is dependent on the systematic and non-exhaustive literature survey for related published research articles, papers, and books concerning heavy metals contamination and related health risk in Bangladesh. A comprehensive literature bank (including both online and offline information) was collected by scrutinous web-surfing as well as comprehending printed materials for identifying the research questions and knowledge gap with respect to heavy metal contamination and its impact on food sate on environmental sustainability in Bangladesh. The review process involved the selection of thematic areas and narrowing down to wellsuited keywords to extract contemporary information. For online materials, the popular academic search engines viz. Google Scholar, PubMed, Science Direct, Scopas, ResearchGate, Springer, as well as official websites were explored with selected keywords. The used keywords include "heavy metals in Bangladeshi foodstuffs", "Heavy metal toxicity", "Heavy metal contamination", "Heavy metals in the food chain", "Arsenic situation in Bangladesh", "Regulation for a safe level of heavy metals in foodstuffs", "Heavy metals pathways to food", "Risk assessment for heavy metals in foods", and "Removal of heavy metals". The offline materials were obtained from the institutional library as well. At first, the abstract and major findings of secondary materials were critically overviewed to assess the relevancy to be included in the current study. Later on, the eligible materials were sorted (e.g., abstracts, full text, and salient findings) based on the research frame of the study. No specific timeline or verified methodology (e.g., PRISMA) was applied during selection and reviewing the information source. However, the screened references were scrutinized and 
summarized to build-up the story focusing on the presence of heavy metals in foodstuffs, the channel of contamination, associated health risk, and existing regulation to reduce the effect from Bangladesh's perspective. To avoid any potential redundancies, the data derived from previously published articles focusing on the abundance of heavy metals and salient features deciphering the resulting health risks were arranged in two separate tables to relate the heavy metal contamination in Bangladesh and its potential trophic transfer to affect the food chain. Finally, the research gap regarding the studied area and potential steps for alleviating the situation were suggested through rational exposition.

\section{Current scenario of heavy metals contamination in Bangladesh}

In Bangladesh, most arable land, edible crops (e.g., cereals and vegetables), fish, dairy products, and freshwater sinks, including urban rivers and lakes, are badly contaminated with heavy metals (Islam et al. 2018a). For instance, a research study on heavy metals in common vegetables and fruits collected from 30 agroecological zones of Bangladesh and the resulting risk assessment for human consumption showed that the concentrations of lead in mango and cadmium in tomatoes were above the MTL set by the WHO/United Nations Food and Agriculture Organization (FAO) (Shaheen et al. 2016). A similar study of cultured fish species commonly consumed in Bangladesh, namely rahu (Labeo rohita), tilapia (Oreochromis mossambicus), and pangas (Pangasius pangasius) (Ahmed et al. 2015b), demonstrated that tilapia contained a higher concentration $(1.486 \mathrm{mg} / \mathrm{kg})$ of arsenic than the other two fish species, suggesting the potential risk for carcinogenic and chronic toxicity due to the continuous consumption of these abundant and cheap fish species by inhabitants of contaminated areas. In addition, the accumulation of trace metals in common freshwater fish species (Pangasianodon hypophthalmus) and the potential health risk due to frequent consumption by a human are reported in a recent study (Maruf et al. 2021). Although the concentration of heavy metals was below the hazard level in the studied fish species, prolonged consumption of contaminated fish may lead to widespread chronic carcinogenesis and other health complexities (Hasan et al. 2020). In contrast, a hazardous concentration of copper was detected in giant freshwater prawns from the Buriganga River in Dhaka, the capital of Bangladesh (Ahmed et al. 2015a). Additionally, arsenic, chromium, cadmium, nickel, and lead concentrations above the safe MTLs were found in cereals, pulses, fruits, and vegetables grown in northern Bangladesh (Kormoker et al. 2020) posing a potential carcinogenic risk to residents and especially to children and infants that could be affected through the food webs (Table 1).

Heavy metals have been identified in various sources in Bangladesh such as agricultural soils near industries (Zakir et al. 2015; Proshad et al. 2020); groundwater samples (Shamsudduha et al. 2019); common foods, including cereals, vegetables, fruits, or other raw and fresh products (Ahmed et al. 2016a; Shaheen et al. 2016; Ahmed et al. 2019a); freshwater rivers; and fish species that inhabit the rivers (Ahmed et al. 2015a; Kibria et al. 2016; Hasan et al. 2021). Heavy metal toxicity was found in groundwater samples in Dhaka with lead $(\mathrm{Pb})$ as the predominant toxic metal followed by arsenic (As) (Sharmin et al. 2020). The findings of that study indicate that water quality of Dhaka is unsuitable as per the guidelines of WHO (permissible value for As and $\mathrm{Pb}$ is set $0.01 \mathrm{mg} / \mathrm{l}$ concerning the drinking water quality assessment) (Sharmin et al. 2020). Based on risk factor analysis of the studied samples by Sharmin and coworker, adults and children in the central-western areas of Dhaka were warned of potentially carcinogenic and noncarcinogenic health risks. Similarly, the prevalence and potential risks of heavy metals were also assessed for water samples in the Jamalpur district of Bangladesh (Zakir et al. 2020b). Like Dhaka, $95 \%$ of the tested water samples from Jamalpur district were also unsuitable for drinking, whereas $18 \%$ of surface water and $25 \%$ of subsurface water samples were suitable only for irrigation as per WHO permissible limits of tested heavy metals (i.e., WHO permissible limit for total $\mathrm{Cr}$ $0.05 \mathrm{mg} / \mathrm{l}$ and Cd $0.003 \mathrm{mg} / \mathrm{l}$ ) (Zakir et al. 2020b). However, the suitability test for water quality index was performed by the empirical equation termed heavy metal evaluation index (HMEI) as suggested by the earlier research (Singh et al. 2017). If the HMEI is greater than 1, the water quality is unsuitable in terms of heavy metal contamination. Thus, both adults and children in the examined district were warned of the potential carcinogenic and noncarcinogenic health risks from chronic exposure to those contaminated waters. In a contemporary study, heavy metals along with polycyclic aromatic hydrocarbons were detected in rooftop garden soils and corresponding cultivated vegetables (Tusher et al. 2020). Urban rooftop gardens are likely to be more polluted than the suburban rooftop gardens. The results of this study were particularly worrying in terms of food safety, as a considerable city dwellers rely on rooftop agricultural products as a source of fresh and toxin-free fruits and vegetables in Bangladesh. The urban agriculture based on rooftop gardening is a popular concept in the major cities of Bangladesh, where the soil may be considered as a hidden sink of many toxic pollutants including heavy metals due to lack of specific research data. There is an urgent need for a meticulous monitoring and policymaking approach toward quality assessment of the urban agricultural practices to combat the hidden threat of heavy metals and associated 


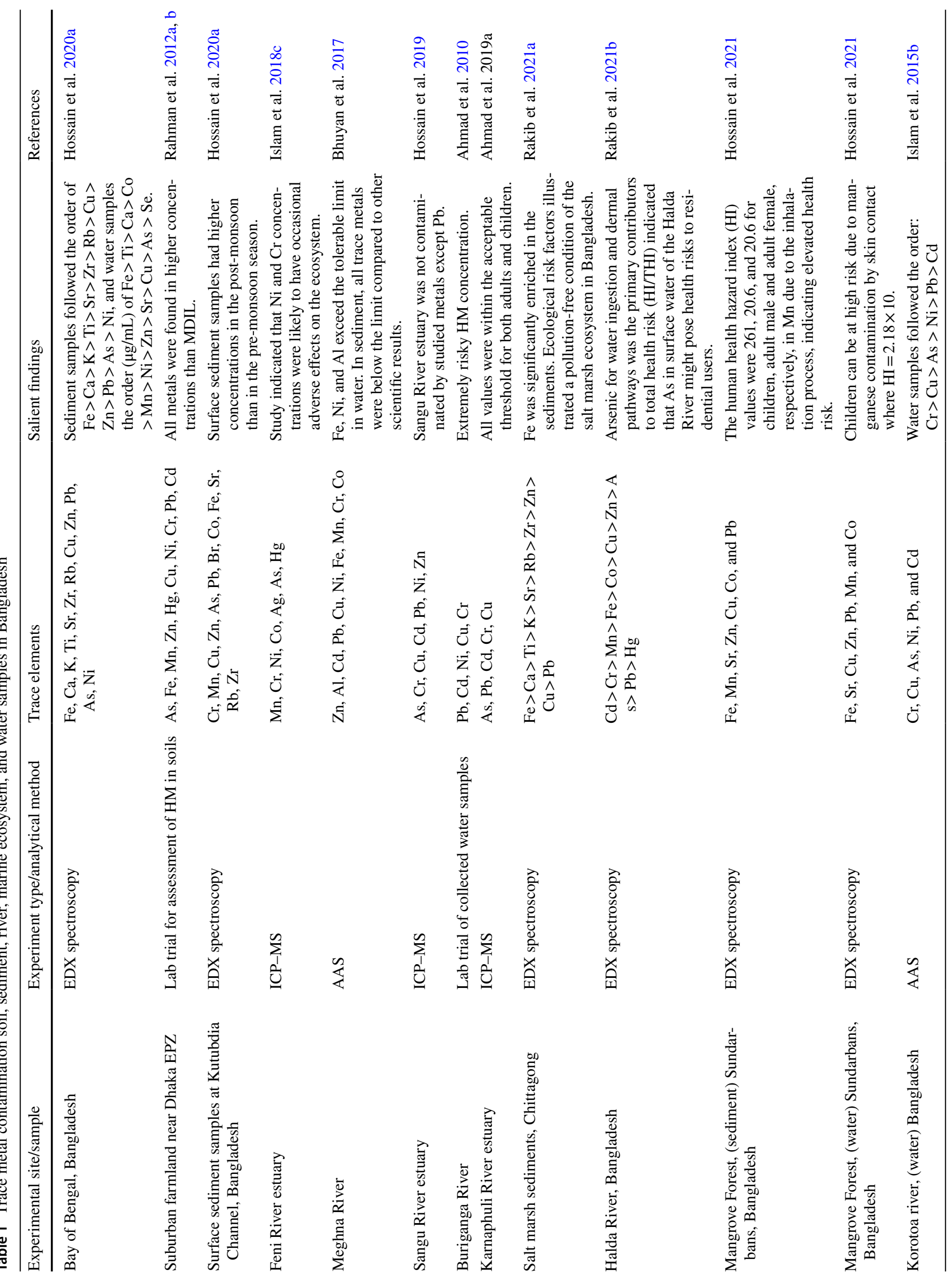


toxins in the food system. Saha et al. (2016) noticed the transfer of six major trace metals (e.g., $\mathrm{Cu}, \mathrm{Ni}, \mathrm{Cd}, \mathrm{Pb}, \mathrm{Cr}$, and $\mathrm{Zn}$ ) from the soils to the mature plants and leaves of tobacco in Kushtia district of Bangladesh. Thus, heavy metals can be found in different environmental components and can be taken up by plants in fields near industrial and urban facilities (Table 2). However, the identification of the primary sources of heavy metal contamination in Bangladesh is sparingly studied (Islam et al. 2018a; Ratul et al. 2018; Zakir et al. 2020b), and further research is needed to determine the environmental fate and transport pathways of heavy metals at contaminated sites in Bangladesh. The environmental sustainability of the ecosystems of Bangladesh is largely dependent on the hidden threat and uncertainty of the heavy metals contamination and their potential toxicity through the food webs of Bangladesh. Meticulous synchronization of local studies with global contemporary legislation concerning heavy metals contamination is needed to be explored toward enhancement of food safety of Bangladesh.

\section{Trophic transfer of heavy metals through food webs in Bangladesh}

Heavy metal contamination is caused by natural and anthropogenic activities, polluting most components of ecosystems such as agricultural and suburban soils, urban waterways, and sediments (Islam et al. 2018b; Ratul et al. 2018; Kumar et al. 2019). Improper disposal of industrial effluents, application of heavy metal-containing agrochemicals (fertilizers, pesticides, etc.), mining, the release of heavy metals from poultry manure, and weathering of trace metal-rich rocks and minerals are considered the primary sources, and subsequent transport of heavy metals in the surrounding environments has been documented globally (Gupta et al. 2018; Kumar et al. 2019; Zakir et al. 2020a). Agricultural and suburban soils, freshwater rivers, and groundwater are the ecological components most affected by heavy metals in Bangladesh (Ahmad and Goni 2010; Islam et al. 2018a, 2018b). Although global studies have revealed the transport pathways of heavy metals in various environmental matrices (Gupta et al. 2018; Kumar et al. 2019), primary sources and transport pathways are not well studied in Bangladesh (Kibria et al. 2016; Islam et al. 2018a), which needs to be investigated to explore the trophic transfer of trace metals through the food chain of Bangladesh.

Arsenic in contaminated groundwater has extensively been studied in Bangladesh due to its acute and chronic toxicity that leads to severe health complications (Flanagan et al. 2012; Ahmad et al. 2018; Huq et al. 2020). Inorganic arsenic salts and toxic arsenate and arsenite derived from arsenic ores after natural or anthropogenic intervention (Chakraborti et al. 2015) have also been found in shallow 


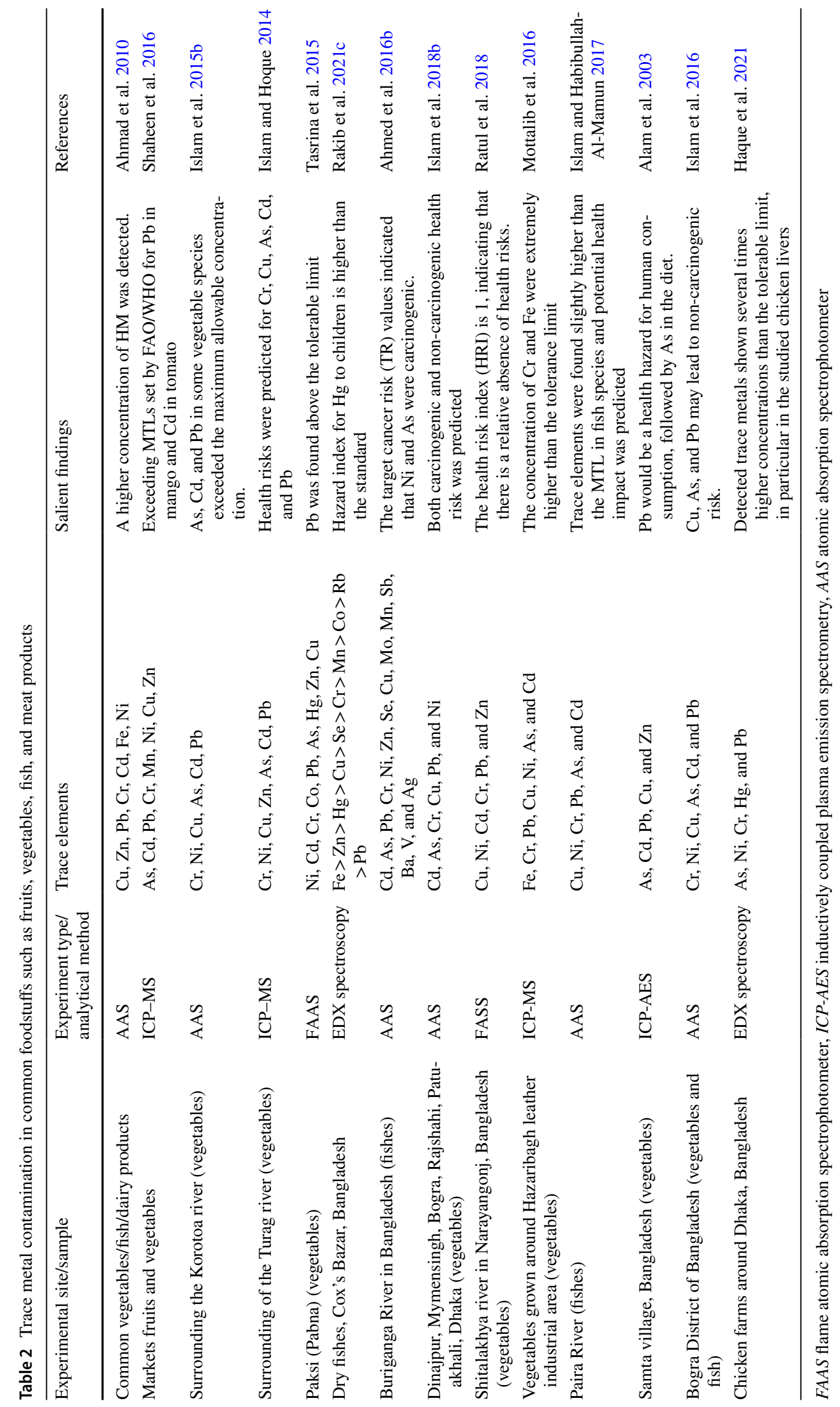


groundwater. The irrigation with arsenic-contaminated groundwater and improper mining of arsenic ores have been shown to further facilitate arsenic transport to surrounding environment (Flanagan et al. 2012; McArthur et al. 2016). Arsenic pollution could affect the groundwater, farming land irrigated with polluted groundwater. The evidence of food web toxicity of human due to chronic exposure of arsenic-contaminated water and foodstuffs is well established (Islam et al. 2017a, b; Rahman et al. 2018; Huq et al. 2020; Mihajlov et al. 2020). Contamination with several heavy metals was also found in agricultural lands near the Dhaka export processing zone area (Rahman et al. 2012a, b; Hasnine 2017), and was mainly attributed to the release of untreated industrial effluents and their poor management. Similarly, heavy metals have been spread from industrial activities to suburban soils and nearby farmlands in large industrial cities in Bangladesh (Zakir et al. 2015; Begum and Huq 2016). Tanneries with lack of environmental treatment discharge a large amount of heavy metals through their effluents. In the Dhaka City, about 200 tanneries discharge nearly 95,0001 or $21,000 \mathrm{~m}^{3}$ of untreated effluents along with 115 tons of solid wastes daily into the surrounding environment (Islam et al. 2021a). Earlier studies reported the transfer of heavy metals to surrounding soils through contaminated effluents derived from the leather industry in Dhaka (Mottalib et al. 2016), nearby groundwater through coal effluents derived from the coal mine of Barapukuria coal basin, Bangladesh (Habib et al. 2020). Thus, heavy metal-contaminated soils and groundwaters may act as the secondary sources of heavy metals, as their uptake by plants may cause food chain toxicity through the consumption of crops grown on contaminated arable land, posing a critical concern about the trophic transfer of heavy metals from primary sources through the human food chain in Bangladesh.

Freshwater rivers are another important sink of heavy metals in Bangladesh. Most urban rivers in Bangladesh are dumping sites for industrial, domestic, and agricultural waste, and are usually treated improperly (Islam et al. 2020b). As a result, almost all freshwater rivers are polluted with heavy metals from industrial effluents (Kibria et al. 2016). Among the studied rivers, Buriganga, a major river near Dhaka, was heavily polluted with heavy metals, followed by other urban rivers (e.g., Dhaleshwari River), while tracing elements accumulated in vegetables through irrigation with contaminated river water (Ratul et al. 2018; Hasan et al. 2020). Similarly, the variability of the water quality of other major rivers including transboundary streams of such as the Ganges for Indian subcontinents, and Halda for Bangladesh were also dominated by the abundance of toxic heavy metals (Bhuyan and Bakar 2017; Islam et al. 2020; Haque et al. 2020). However, the concentration of arsenic varied depending on the sampling site. For instance, shallow tubewells (STW) were found to be the main source of heavy metal contamination in agricultural land through irrigation by contaminated groundwater, while the distance of the sampling site from the STW was positively correlated with reduced heavy metal concentrations (Hossain et al. 2008). A confirmatory study documented heavy metal transfer from Barapukuria coal mine in northern Bangladesh to surrounding agricultural soils (Bhuiyan et al. 2010). Similarly, mining activities in central China were also identified as a potential source of heavy metal contamination (Fan et al. 2017). A recent study based on marine and freshwater aquatic species in South Indian aquatic ecosystems noticed the risky levels of mercury and the potential health risks due to human exposure (Subhavana et al. 2020). It is therefore clear that the cycling of heavy metals into the environment can be driven by urban rivers, industrial activities, improper management of industrial effluents, heavy metal-containing agrochemicals, mining, and other anthropogenic activities as described in the abovementioned tables were illustrated, accordingly (Fig. 1).

The trophic transfer of heavy metals from the primary source to surrounding ecosystems and food webs is a crucial concern for global food safety (Ali and Khan 2019; Kumar et al. 2019) and can be regulated by several transfer factors, such as bioaccumulation, defined as the ratio of metal concentration in an organism's tissue to that in an abiotic medium (Mortuza and Al-Misned 2015); biomagnification, defined as the ratio of metal concentration in an organism to that in the organism's diet (Yarsan and Yipel 2013); and bioconcentration, defined as the ratio of metal concentration in a studied organism to that in water (Chalkiadaki et al. 2014; Ali and Khan 2019). An earlier study focusing on the transfer of heavy metals through various terrestrial food web pathways highlighted the health risks that develop with biomagnification of transported heavy metals from the primary source to consumers (Gall et al. 2015). Moreover, heavy metals have been detected in raw cow milk, suggesting that the biomagnification and subsequent transfer of heavy metals from the primary source to cow milk through grazing is a global threat to the food chain for infants, children, and adults (Boudebbouz et al. 2021; Haakonde et al. 2021). Additionally, the risk of heavy metals through dietary exposure in the case of the Italian population was documented (Filippini et al. 2019). Hence, the transport of heavy metals through the food chain should be treated as a future threat to global food safety related to terrestrial and aquatic ecosystems.

Heavy metals have been detected in major food products of Bangladesh, including cereals, vegetables, fruits, water, or fish (Hezbullah et al. 2016; Islam et al. 2018a). A comparative study of common leafy vegetables collected from industrial and nonindustrial regions showed that nonessential heavy metals accumulated most in vegetables from the industrial regions of Bangladesh (Naser et al. 2018). 


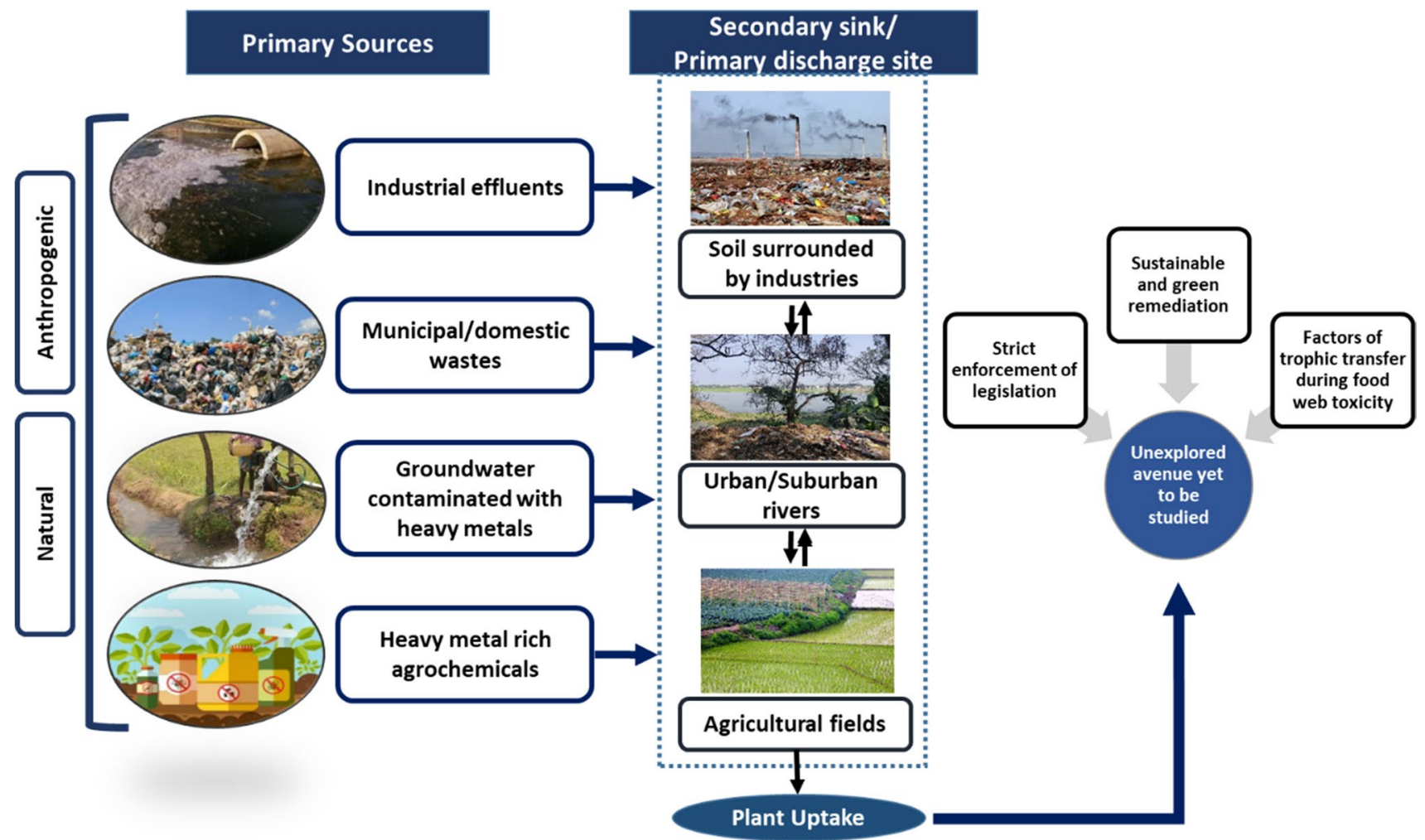

Fig. 1 Schematic presentation of existing situations (primary source, fate, etc.) of heavy metal pollution through food webs of Bangladesh. The sources including the natural and anthropogenic sources are con-

Furthermore, the trophic transfer of heavy metals from rivers via human consumption of fish and other freshwater animals was confirmed in previous studies on urban rivers of Bangladesh (Rahman et al. 2012a, b; Ahmed et al. 2015a). Despite the numerous studies supporting the pervasive presence of heavy metals in common foodstuffs of Bangladesh (Shaheen et al. 2016; Zakir et al. 2020a), the bioconcentration and bioaccumulation of heavy metals during trophic transfer have been largely overlooked. Although several encouraging multivariate techniques and statistical modeling were attempted to explore the spatial distribution of trace metals and related co-contaminants in the drinking and groundwater (Islam et al. 2017a, b, 2019), the meticulous toxicity profile of heavy metal contamination and resulting health risk is not studied vastly. Similarly, the arsenic mobilization process was investigated through the hydrogeochemical evolution in Bangladesh (Saha et al. 2020), which may pose a potential health risk to the habitants through drinkable groundwater. As a consequence, the nutritional value of vegetables and fruits can be significantly reduced due to unexpected contamination (Khan et al. 2014) with essential trace metals introduced by fertilizer application and/or nonessential trace metals deposited due to poor management of municipal and industrial waste (Shaheen et al. 2016; Kumar et al. 2019). sidered. This figure is drawn by the author using symbolic image or photos from primary sources

Therefore, further studies are needed to clarify the impact of bioaccumulation and biomagnification of heavy metals and to combat food adulteration and ensuring sustainable food safety in Bangladesh.

\section{Uncertainty of health risks and legislation associated with heavy metals contamination in Bangladesh}

Heavy metals are toxic to humans even in trace amounts after acute or chronic exposure, severely affecting the major organs of adults, such as the brain, kidney, central nervous system, heart, reproductive, and digestive systems as well as the physiology of children, including the nervous system, kidney, brain, and circulation (Gupta et al. 2018; Kumar et al. 2019). Oral ingestion of nonessential heavy metals (arsenic, lead, mercury, or cadmium) by humans or animals can cause chronic or acute toxicity manifested as nausea, vomiting, irregular bowel movements, motor neuron dysfunction, vision and hearing impairment, brain and heart damage, or hypertension, etc. (Jomova et al. 2011; Flora et al. 2012; Mari et al. 2018). Moreover, internal and cellular toxicity may lead to the disruption of nerve cells and 
DNA structure and delay mitochondrial metabolic processes such as ATP synthesis and oxidative photophosphorylation (Rehman et al. 2018; Lai et al. 2018; Zafarzadeh et al. 2018; Kumar et al. 2019). A recent study noticed the bioavailability of heavy metals and toxic metalloids in the suspended particulate matter of air, which may pose a hidden threat to human health through inhalation of atmospheric air (Ren et al. 2021). Similarly, arsenic was detected in the air samples, and the studied urine samples were derived from the habitants of the copper smelter regions (Skoczynska et al. 2021). Therefore, in the global context, these severe complications along with constant exposure to the food product or environmental contamination with toxic heavy metals may even lead to death.

Although global research on heavy metal toxicity is advancing at the cellular and genomic level to clarify the effect of heavy metals on human metabolism (Renu et al. 2021), studies on heavy metal contamination and its health implications in Bangladesh are at a very early stage (Islam et al. 2018a). Several research projects have reported the occurrence of hazardous concentrations of heavy metals in common foods such as cereals, vegetables, fruits, and fish (Islam et al. 2015a; Ahmed et al. 2016b; Ratul et al. 2018; Proshad et al. 2020; Zakir et al. 2020a). However, the health risks of the identified heavy metals were expressed as a hazard index or hazard quotient of the estimated daily intake and acceptable daily intake parameters. In contrast, a contemporary study based in Kuwait reported the presence of heavy metals derived from the household dust of air filters, where, household heating, ventilation, and air-conditioner are considered the key point sources for those toxic metals and metalloids (Al-Harbi et al. 2021). Similarly, the topsoilderived heavy metals and their potential exposure to health risks were reported in central China (Li et al. 2020a, b), where the untreated discharge from the factory was blamed for the potential source of heavy metal to the nearby arable soils. However, recent studies have noticed the considerable concentration of detected heavy metals in the school dust of Dhaka City and indoor dust samples derived from the Dhaka EPZ area of Bangladesh (Rahman et al. 2021a, 2021b), which are the critical risk during unconscious inhalation. Thus, in Bangladesh, there is an urgent need to expedite the potential airborne heavy metals, which may pose a hidden threat to critical respiratory complexities during this COVID 19 pandemic. In a recent study, salinity-induced dissolved organic materials (DOM) have been noticed to accelerate the co-contamination of heavy metals in the southern coastal region of Bangladesh (Kabir et al. 2021), which is a promising sector of future study regarding co-exposure toxicity and vector transport pathways of heavy metals with related emerging environmental pollutants. Moreover, to combat the hidden threat to food safety, the studies regarding complex metabolism and cellular toxicity of heavy metals in human health and their subsequent effects on food webs including terrestrial, aquatic, and air particulate samples should also be emphasized in Bangladesh (Fig. 2).

\section{Advanced yet unnoticed approaches for remediation of heavy metals in Bangladesh}

Advanced studies on heavy metal remediation have been a priority in the development of environmental strategies. Among them, microbial approaches and heavy metal-tolerant microbes have proven to be the most promising options (Rahman 2020). The complex mechanisms of microbial remediation, including chemical-microbial interactions, were recently elucidated (Yin et al. 2019; Islam et al. 2021b), while heavy metal-tolerant microbes were considered potential candidates for advanced genetic development for sustainable field applications. Nanotechnology-based approaches have also been adopted to recover heavy metals from contaminated sites (Kumar et al. 2019; Nasir et al. 2019), while phytoremediation, a comparatively cheaper plant-based technology, was used to clean heavy metal-contaminated areas based on mechanisms such as phytoaccumulation (Muthusaravanan et al. 2018). A novel arsenic-hyperaccumulating fern (Pteris vittata) is widely reported as a sustainable phytoremediation tool for reclamation of arsenic-contaminated soils (da Silva et al. 2018).

Carbon-based biochar is another ideal adsorbent for heavy metal reclamation from the contaminated sites (Mansoor et al. 2020). The variation of pyrolysis temperature, redox complexation, and addition of organics was identified as the key factors for effective sorption of heavy metals through modified biochar (Li et al. 2017). Therefore, several significant modifications of biochar were adopted for the innovative remediation of toxic metal-contaminated sites. A recent observation suggests a new "vermibiochar" through the activation of biochar by potential earthworms by the stimulation of exogenous enzyme activities to establish an efficient and cheap recovery tool for heavy metal remediation from the contaminated soil and water systems (Yuvaraj et al. 2021). Similarly, an innovative and cheap "hydrogel" derived from the food waste was utilized as the food waste valorization approach for simultaneous application of soil health improvement and effective remediation of heavy metal-contaminated soils (Zhou et al. 2021). This hydrogel was prepared by combining montmorillonite clay minerals with urea and poly(acrylic) acid. The multifaceted chemical properties of this hydrogel may be advantageous for improving the oxidation reduction of the heavy metal-contaminated sites along with increasing soil's physical and chemical properties toward fertility status of the soils. Thus, the modification of biochar- or carbon-based adsorbents, vermiremediation, 


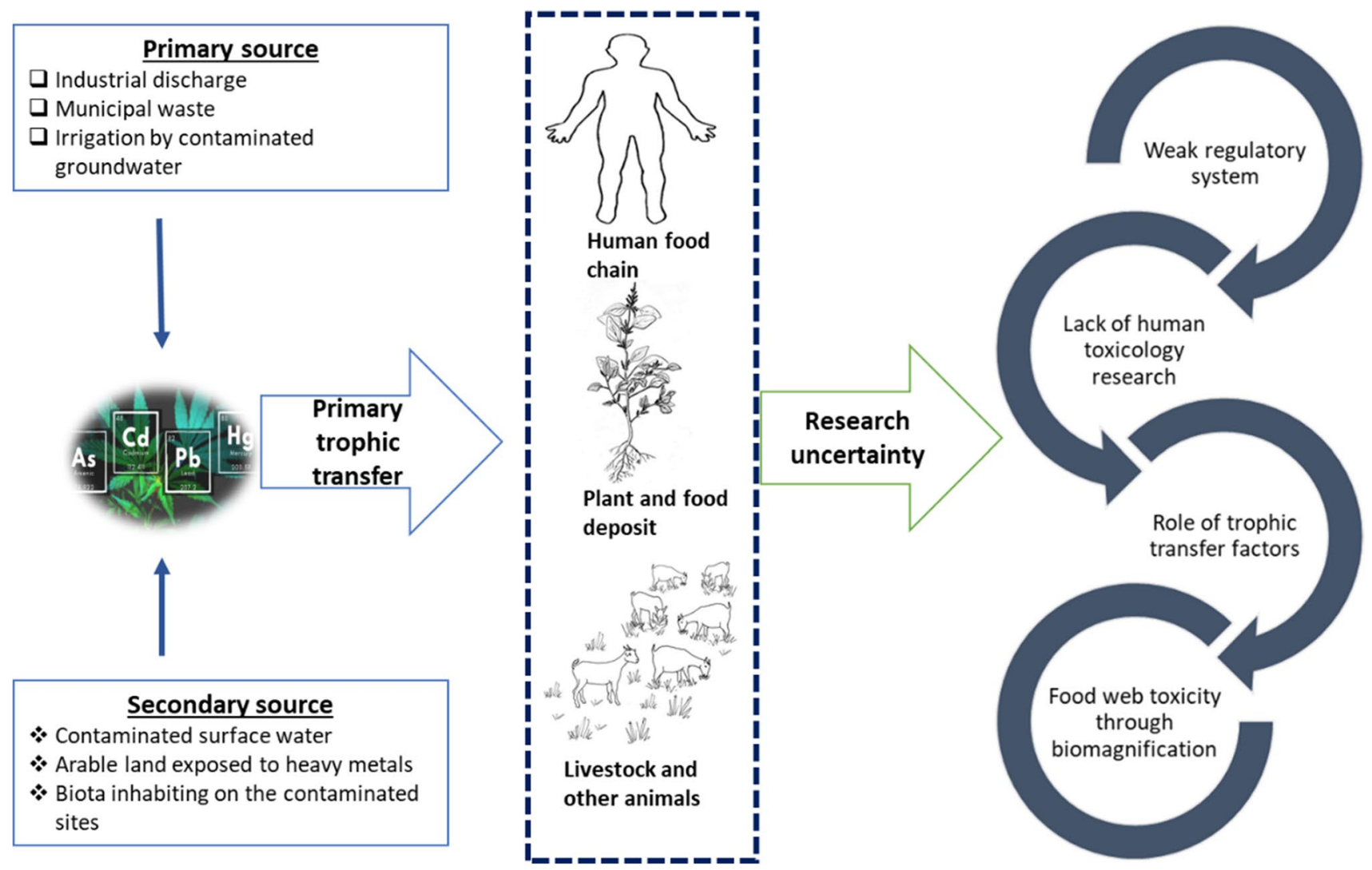

Fig. 2 Transport pathways, hidden threat, trophic transfer mediated by several transfer factors (e.g., biomagnification and biotransformation factors), and research uncertainty of heavy metal contamination in Bangladesh

and food waste-derived hydrogels are considered the sustainable approaches for heavy metal remediation due to the cost-effectiveness, and simplicity in applications. However, such sustainable techniques have not been widely applied in Bangladesh except for a recent study, which reported the potential use of a salt marsh macrophyte (Porteresia sp.) for the uptake and translocation of various toxic heavy metals (Hossain et al. 2021). Further adaptive investigations could be expanded to explore the cheap, sustainable, and innovative heavy metal remediation strategies in Bangladesh.

\section{Challenges in environmental regulations for heavy metal pollution in Bangladesh}

Heavy metal risk assessments in foodstuffs have been carried out in Bangladesh based on WHO and FAO safety standards (Islam et al. 2020a; Zakir et al. 2020b). Furthermore, while several studies have focused on estimating heavy metal levels in samples collected in Bangladesh, no integrated safety guidelines for assessing MTLs (maximum tolerable limits) have yet been established (Islam et al. 2018a, 2018b). It indicates a significant regulatory gap in heavy metal contamination in Bangladesh. There are several government entities such as Bangladesh Atomic Energy Commission (BAEC) and Bangladesh Standard and Testing Institute (BSTI) for controlling food safety including the contamination from the toxic heavy metals in the foodstuffs. The basic function of BAEC is to monitor the food and environmental samples with respect to the abundance of toxic heavy metals (Islam et al. 2015a; Islam et al. 2018a). In addition, recent findings on heavy metal contamination should be integrated to combat the prevailing research shortcomings in the food safety mission of the Bangladesh Food Safety Authority (BFSA 2017). The establishment of BFSA (based on Food Safety Act, 2013) ensures food safety in terms of toxins (heavy metals, pesticides, mycotoxins, etc.) in the common fresh and processed foodstuffs of Bangladesh. In addition, the National Food Safety Laboratory of Public Health Institution (PHI) has established a reference laboratory to monitor heavy metals and pesticides in the market available foodstuffs (BFSA 2017). The other regulatory bodies such as INARC (under the Institute of National Analytical Research and Services, BCSIR) are also fostering the food safety campaign by ensuring quality assessment of toxic heavy metals and related pollutants in the foodstuffs (INARS 2021). Despite several encouraging approaches acting to combat the heavy metal contamination in Bangladesh, several challenges such 
as poor enactment of the existing legislation due to ignorance among the stakeholders, lack of unified and reference analytical protocol for the comparative study of the toxic heavy metals in the common foodstuffs and environmental matrices, and adaptation of the green and sustainable management strategies for heavy metal polluted sites are considered as the bottlenecks of heavy metal research in Bangladesh.

In contrast, a recent review pointed out the heavy metal contamination in the farming land and following food chain toxicity toward food safety in China (Qin et al. 2020). Policymaking advocacy and sustainable remediation of heavy metal contamination were suggested to combat the heavy metals as a barrier to food safety in Chinese food webs. Similarly, a recent paper summarized the variations of bioaccessibility of heavy metals in the food webs through a comparison of in vitro and in vivo bioassay ( $\mathrm{Li}$ et al. 2020a, b). The finding of that study indicates a significant variation of metal bioaccessibility due to various metabolic factors from source to sink pathways. However, Bangladesh is the worst victim of major environmental disasters, including heavy metal contaminations in the food webs. Thus, there is a need for the synchronization of global legislation and the health risks of heavy metals to foster the safety of foodstuffs in Bangladesh. The major institutions and their regulatory framework for addressing heavy metal contamination including related acts and legislations at global and at level of the government of Bangladesh are illustrated in Fig. 3.

\section{Conceptual implication for management of heavy metal contamination in Bangladesh}

During the last decade, heavy metal contamination in Bangladesh is studied extensively. Those earlier published reports have already noticed the abundance of heavy metals in the common foodstuffs (fruits, vegetables, and fishes), river and groundwater, and soils and sediments nearby the industries and suburban soils (Islam et al. 2018a; Habib et al. 2020). However, to date, the sustainable management of heavy metal contamination was not suggested precisely in Bangladesh's perspective. This study identified several untapped research themes and the possible holistic solution through a conceptual implication approach (Fig. 4), which is the pioneering step toward policy implication and prospective of heavy metal research in Bangladesh. The existing studies of heavy metals should be corroborated with the untapped research themes to overcome the current research uncertainties of heavy metal contamination in Bangladesh. Among the unveiled research avenue, unified strict enforcement of the existing regulatory framework with possible contemporary amendments will boost the current legislation of heavy metal contamination for improving local food safety in Bangladesh. In addition, the factors of trophic transfer of heavy metals in various ecosystems, and following food chain toxicity including bioaccumulation and biotransformation
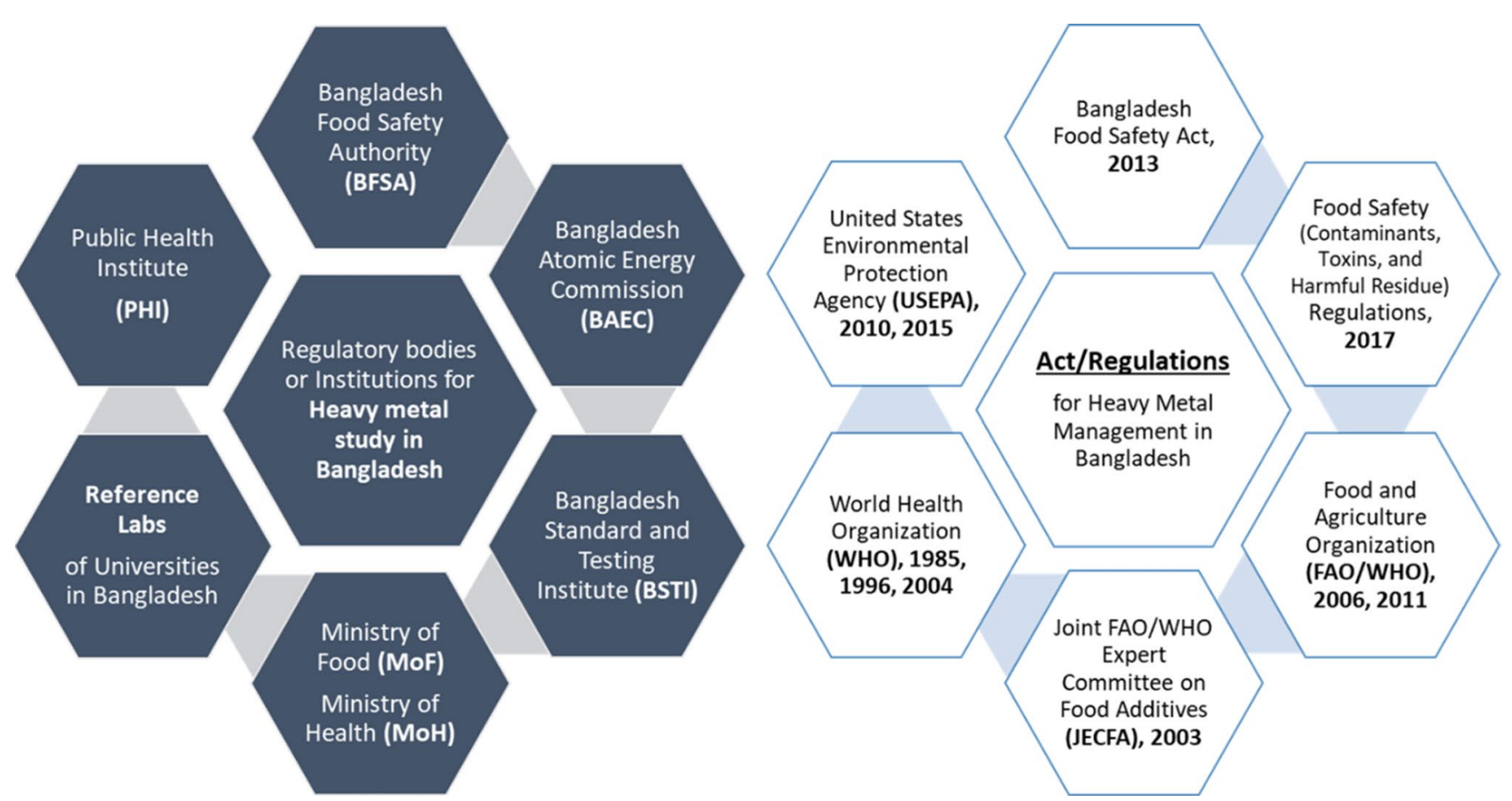

Fig. 3 National and global regulatory bodies and respective institutions involved in regulatory acts and legislative monitoring, and safety regulations of heavy metal contamination in Bangladesh 


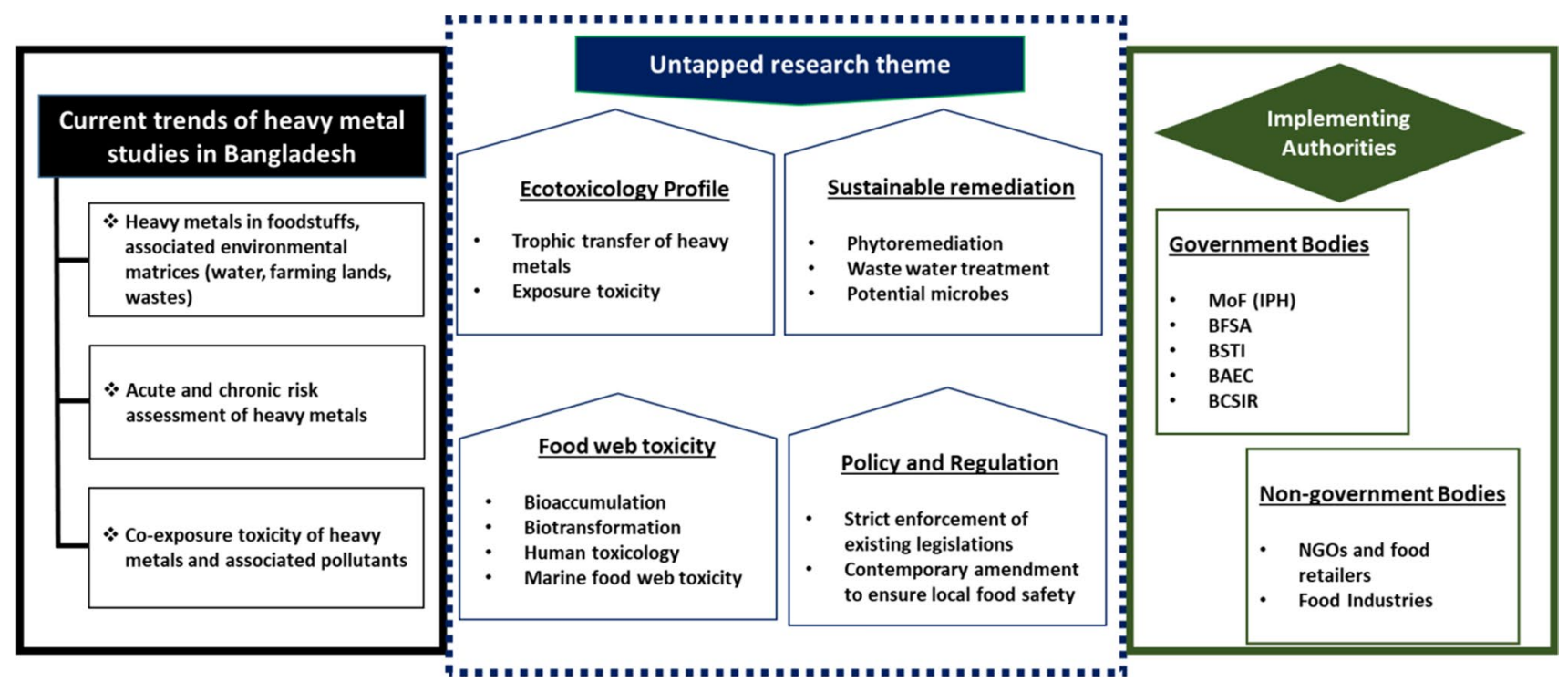

Fig. 4 Conceptual policy framework for sustainable management of heavy metal contamination in Bangladesh for fostering the food safety and environmental sustainability

should be investigated. Furthermore, economically viable and sustainable remediation of heavy metals from the contaminated matrix should be merged with advanced global remediation (e.g., phytoremediation, microbial remediation, and wastewater treatments). Another important sink of heavy metals and co-existence of other organic pollutants of Bangladesh in the Bay of Bengal (Hossain et al. 2020a, b, c), which is not studied meticulously for food webs transfer of heavy metals to the human food chain (Islam et al. 2021), except few empirical seafood heavy metals contamination studies (Baki et al. 2018; Biswas et al. 2021). Thus, a meticulous evaluation of existing research gaps and global policy synchronization should be implemented through a logical merger of all possible stakeholders (e.g., government bodies-Ministry of Food, Bangladesh Standard and Testing Institute-BSTI, Bangladesh Food Safety Authority-BFSA, and non-government stakeholders) for enhanced management of heavy metal contamination in Bangladesh.

\section{Conclusion and research perspective}

This review summarizes and updates scenarios of toxic heavy metal contamination and related health risk in food webs and associated environments in Bangladesh. It also explores the transformation of toxic trace metals into food webs in Bangladesh. Our literature survey revealed that current challenges of heavy metal contamination in the food chain are mainly caused by improper management of industrial discharge, poor enforcement of standard guidelines and regulations, unavailability of research data concerning sustainable management, and limited public awareness. These limitations ultimately pose a hidden threat to food safety in Bangladesh. Policy formulation in synchronicity with global regulatory policy and research efforts is therefore needed to overcome these bottlenecks for the mitigation of heavy metal contamination in Bangladesh. In addition, an extensive future investigation on the human and plant metabolism of heavy metals is needed. Regular monitoring of analytical findings from well-equipped unified laboratories is needed to ensure local food safety. Furthermore, potential health risks due to the exposure to hazardous heavy metals and molecular toxicology through clinical trials need to be explored. To sum up, strengthening sanitary systems and adopting contemporary remediation approaches (e.g., bioremediation, phytoremediation, nano-remediation, and advanced catalysis) are needed to sustainably combat heavy metal contamination to ensure food safety in Bangladesh. The existing challenges and possibilities of further toxic metal contamination in Bangladesh warrant future critical evaluation following the recommended conceptual policy frameworks.

Acknowledgements Authors are grateful to IBGE, BSMRAU, Gazipur, Bangladesh for proofreading, plagiarism checking, and other technical supports throughout the writing period of the paper.

Availability of data and materials Data sharing is not applicable to this article as no datasets were generated or analyzed during the current study. 
Author contribution Aniruddha Sarker and Jang-Eok Kim: conceptualization, methodology, data curation, and writing — review and editing. Abu Reza Md. Towfiqul Islam and Muhammad Bilal: conceptualization and writing - review and editing. Md. Refat Jahan Rakib and Mohammed M. Rahman: writing - original draft and visualization. Rakhi Nandi: methodology and writing — review and editing. Tofazzal Islam: conceptualization, methodology, writing — review and editing, and supervision.

\section{Declarations}

Ethics approval and consent to participate Not applicable.

Consent for publication Not applicable.

Competing interests The authors declare no competing interests.

\section{References}

Ahmad JU, Goni MA (2010) Heavy metal contamination in water, soil, and vegetables of the industrial areas in Dhaka, Bangladesh. Environ Monit Assess 166:347-357

Ahmad MK, Islam S, Rahman S, Haque M, Islam MM (2010) Heavy metals in water, sediment and some fishes of Buriganga River, Bangladesh. Int J Environ Res 4(2):321-332

Ahmad SA, Khan MH, Haque M (2018) Arsenic contamination in groundwater in Bangladesh: implications and challenges for healthcare policy. Risk Manag Healthc Policy 11:251-261. https://doi.org/10.2147/RMHP.S153188

Ahmed MK, Baki MA, Islam MS et al (2015a) Human health risk assessment of heavy metals in tropical fish and shell fish collected from the river Buriganga, Bangladesh. Environ Sci Pollut Res 22:15880-15890

Ahmed MK, Shaheen N, Islam MS, Habibullah-al-Mamun M, Islam S, Mohiduzzaman M, Bhattacharjee L (2015b) Dietary intake of trace elements from highly consumed cultured fish (Labeo rohita, Pangasius pangasius and Oreochromis mossambicus) and human health risk implications in Bangladesh. Chemosphere 128:284-292

Ahmed MK, Shaheen N, Islam MS et al (2016a) A comprehensive assessment of arsenic in commonly consumed foodstuffs to evaluate the potential health risk in Bangladesh. Sci Total Environ 544:125-133

Ahmed MK, Baki MA, Kundu GK, Islam MS, Islam MM, Hossain MM (2016b) Human health risks from heavy metals in fish of Buriganga river, Bangladesh. SpringerPlus 5(1):1-12

Ahmed AS, Sultana S, Habib A, Ullah H, Musa N, Hossain MB, Sarker MSI (2019a) Bioaccumulation of heavy metals in some commercially important fishes from a tropical river estuary suggests higher potential health risk in children than adults. PLoS One 14(10): 0219336

Ahmed N, Bodrud-Doza M, Islam ARMT, Hossain S, Moniruzzaman M, Deb N, Bhuiyan MAQ (2019b) Appraising spatial variations of as, $\mathrm{Fe}, \mathrm{Mn}$ and $\mathrm{NO}_{3}$ contaminations associated health risks of drinking water from Surma basin, Bangladesh. Chemosphere 218:26-740

Alam MGM, Snow ET, Tanaka A (2003) Arsenic and heavy metal contamination of vegetables grown in Samta village, Bangladesh. Sci Total Environ 308(1-3):83-96

Al-Harbi M, Alhajri I, Whalen JK (2021) Characteristics and health risk assessment of heavy metal contamination from dust collected on household HVAC air filters. Chemosphere 277:130276
Ali H, Khan E (2019) Trophic transfer, bioaccumulation, and biomagnification of non-essential hazardous heavy metals and metalloids in food chains/webs-concepts and implications for wildlife and human health. Human Eco Risk Assess 25(6):1353-1376

Baki MA, Hossain MM, Akter J, Quraishi SB, Shojib MFH, Ullah AA, Khan MF (2018) Concentration of heavy metals in seafood (fishes, shrimp, lobster and crabs) and human health assessment in Saint Martin Island, Bangladesh. Ecotox Environ Safe 159:153-163

Begum M, Huq SI (2016) Heavy metal contents in soils affected by industrial activities in a southern district of Bangladesh. Ban J Sci Res 29:11-17

BFSA (2017) Bangladesh Food Safety Authority. http://www.bfsa. gov.bd/site/view/law/Food-Safety-Act,-2013 (Accessed January 5, 2021)

Bhuiyan MAH, Parvez L, Islam MA, Dampare SB, Suzuki S (2010) Heavy metal pollution of coal mine-affected agricultural soils in the northern part of Bangladesh. J Hazard Mater 173:384-392

Bhuyan MS, Bakar MA (2017) Seasonal variation of heavy metals in water and sediments in the Halda River, Chittagong, Bangladesh. Environ Sci Pollu Res 24(35):27587-27600

Bhuyan MS, Bakar MA, Akhtar A, Hossain MB, Ali MM, Islam MS (2017) Heavy metal contamination in surface water and sediment of the Meghna River, Bangladesh. Environ Nanotech Monit Manag 8:273-279

Biswas KP, Hossain S, Deb N, Bhuian AKM, Gonçalves SC, Hossen MB (2021) Assessment of the levels of pollution and of their risks by radioactivity and trace metals on marine edible fish and crustaceans at the bay of Bengal (Chattogram, Bangladesh). Environments 8(2):13

Boudebbouz A, Boudalia S, Bousbia A, Habila S, Boussadia MI, Gueroui Y (2021) Heavy metals levels in raw cow milk and health risk assessment across the globe: a systematic review. Sci Total Environ 751

Chakraborti D et al (2015) Groundwater arsenic contamination in Bangladesh-21 years of research. J Trace Elem Med Biol 31:237-248

Chalkiadaki O, Dassenakis M, Lydakis-Simantiris N (2014) Bioconcentration of $\mathrm{cd}$ and $\mathrm{Ni}$ in various tissues of two marine bivalves living in different habitats and exposed to heavily polluted seawater. Chem Ecol 30:726-742

da Silva EB, Lessl JT, Wilkie AC, Liu X, Liu Y, Ma LQ (2018) Arsenic removal by as-hyperaccumulator Pteris vittata from two contaminated soils: a 5-year study. Chemosphere 206:736-741

Fan Y, Zhu T, Li M, He J, Huang R (2017) Heavy metal contamination in soil and brown rice and human health risk assessment near three mining areas in Central China. Int J Healthcare Eng:1-9

Filippini T, Tancredi S, Malagoli C, Malavolti M, Bargellini A, Vescovi L, Nicolini F, Vinceti M (2019) Dietary estimated intake of trace elements: risk assessment in an Italian population. Exp Health 9:1-5

Flanagan SV, Johnston RB, Zheng Y (2012) Arsenic in tube well water in Bangladesh: health and economic impacts and implications for arsenic mitigation. Bull World Health Organ 90:839-846

Flora G, Gupta D, Tiwari A (2012) Toxicity of lead: a review with recent updates. Inter Toxicol 5(2):47-58

Gall JE, Boyd RS, Rajakaruna N (2015) Transfer of heavy metals through terrestrial food webs: a review. Environ Monitor Assess 187(4)

Gupta N, Yadav KK, Kumar V, Kumar S, Chadd RP, Kumar A (2018) Trace elements in soil-vegetables interface: translocation, bioaccumulation, toxicity and amelioration- a review. Sci Total Environ 651:2927-2942

Haakonde T, Yabe J, Choongo K, Chongwe G, Nchima G, Islam MS (2021) Uranium contamination of milk from cattle in the uranium-mining area in Siavonga District of Zambia: a preliminary 
human health risk assessment. Bull Natl Res Cent 45(1):1-10. https://doi.org/10.1186/s42269-021-00556-4

Habib MA, Islam ARMT, Bodrud-Doza M, Mukta FA, Khan R, Siddique MAB et al (2020) Simultaneous appraisals of pathway and probable health risk associated with trace metals contamination in groundwater from Barapukuria coal basin, Bangladesh. Chemosphere 242:125183

Haque MM, Niloy NM, Nayna OK, Fatema KJ, Quraishi SB, Park JH et al (2020) Variability of water quality and metal pollution index in the Ganges River, Bangladesh. Environ Sci Pollu Res 27(34):42582-42599

Haque MM, Hossain N, Jolly YN, Tareq SM (2021) Probabilistic health risk assessment of toxic metals in chickens from the largest production areas of Dhaka. Bangladesh Environ Sci Pollu Res:1-13

Hasan MK, Shahriar A, Hossain N, Shovon IK, Hossain A, Jolly YN, Begum BA (2020) Trace metals contamination in riverine captured fish and prawn of Bangladesh and associated health risk. Exp Health 30:1-5

Hasan M, Salam MA, Rahman H, Paul SC, Rak AE, Ambade B, Islam ARMT (2021) Health risk and water quality assessment of surface water in an urban river of Bangladesh. Sustainability 13(12):6832

Hasnine MT (2017) Heavy metal contamination in agricultural soil at DEPZA, Bangladesh. Environ Ecol Res 5:510-516

Hezbullah M, Sultana S, Chakraborty SR, Patwary MI (2016) Heavy metal contamination of food in a developing country like Bangladesh: an emerging threat to food safety. J Toxicol Environ Health Sci 8(1):1-5

Hossain MB, Jahiruddin M, Panaullah GM, Loeppert RH, Islam MR, Duxbury JM (2008) Spatial variability of arsenic concentration in soils and plants, and its relationship with iron, manganese and phosphorus. Environ Pollut 156:739-744

Hossain MB, Shanta TB, Ahmed AS, Hossain MK, Semme SA (2019) Baseline study of heavy metal contamination in the Sangu River estuary, Chattogram, Bangladesh. Mar Poll Bull 140:255-261

Hossain MB, Habib SB, Hossain MS, Jolly YN, Kamal AHM, Idris MH, Rakib MRJ (2020a) Data set on trace metals in surface sediment and water from a sub-tropical estuarine system, bay of Bengal, Bangladesh. Data Brief 31:105911

Hossain MS, Ahmed MK, Sarker S, Rahman MS (2020b) Seasonal variations of trace metals from water and sediment samples in the northern bay of Bengal. Ecotox Environ Safe 193:110347

Hossain MB, Rakib MRJ, Jolly YN, Rahman M (2020c) Metals uptake and translocation in salt marsh macrophytes, Porteresia sp from Bangladesh coastal area Sci Total Environ 144637

Hossain MS, Hossain MB, Rakib MRJ, Jolly YN, Ullah MA, Elliott M (2021) Ecological and human health risk evaluation using pollution indices: a case study of the largest mangrove ecosystem of Bangladesh. Reg Studies Marine Sci 101913

Huq ME, Fahad S, Shao Z et al (2020) Arsenic in a groundwater environment in Bangladesh: occurrence and mobilization. J Environ Manag 262:110318. https://doi.org/10.1016/j.jenvman.2020. 110318

INARS (2021). Institute of National Analytical Research and Services, BCSIR (Available from http://inars.bcsir.gov.bd/) (Accessed September 20, 2021)

Islam MS, Habibullah-Al-Mamun M (2017) Accumulation of trace elements in sediment and fish species of Paira River, Bangladesh. AIMS Environ Sci 4(2):310-322

Islam MS, Hoque MF (2014) Concentrations of heavy metals in vegetables around the industrial area of Dhaka city, Bangladesh and health risk assessment. Int Food Res J 21(6):2121

Islam MS, Ahmed MK, Al-Mamun MH et al (2015a) The concentration, source and potential human health risk of heavy metals in the commonly consumed foods in Bangladesh. Ecotox Environ Saf 122:462-469

Islam MS, Ahmed MK, Raknuzzaman M, Habibullah-Al-Mamun M, Islam MK (2015b) Heavy metal pollution in surface water and sediment: a preliminary assessment of an urban river in a developing country. Ecol Indic 48:282-291

Islam MS, Ahmed MK, Habibullah-Al-Mamun M, Raknuzzaman M, Ali MM, Eaton DW (2016) Health risk assessment due to heavy metal exposure from commonly consumed fish and vegetables. Environ Sys Deci 36(3):253-265

Islam ARMT, Shen S, Bodrud-Doza M, Rahman MA, Das S (2017a) Assessment of trace elements of groundwater and their spatial distribution in Rangpur district, Bangladesh. Arab J Geosci 10(4):95

Islam S, Rahman MM, Islam MR, Naidu R (2017b) Geographical variation and age-related dietary exposure to arsenic in rice from Bangladesh. Sci Total Environ 601-602:122-131. https://doi.org/ 10.1016/j.scitotenv.2017.05.184

Islam MM, Karim MR, Zheng X, Li X (2018a) Heavy metal and metalloid pollution of soil, water and foods in Bangladesh: a critical review. Int J Environ Res Pub Health 15(12). https://doi.org/10. 3390/ijerph15122825

Islam MA, Romić D, Akber MA, Romić M (2018b) Trace metals accumulation in soil irrigated with polluted water and assessment of human health risk from vegetable consumption in Bangladesh. Environ Geochem Health 40(1):59-85

Islam MS, Hossain MB, Matin A, Sarker MSI (2018c) Assessment of heavy metal pollution, distribution and source apportionment in the sediment from Feni River estuary, Bangladesh. Chemosphere 202:25-32

Islam ARMT, Bodrud-Doza M, Rahman MS, Amin SB, Chu R, Al Mamun H (2019) Sources of trace elements identification in drinking water of Rangpur district, Bangladesh and their potential health risk following multivariate techniques and MonteCarlo simulation. Groundwater Sustain Develop 9:100275

Islam MA, Das B, Quraishi SB et al (2020) Heavy metal contamination and ecological risk assessment in water and sediments of the Halda River, Bangladesh: a natural fish breeding ground. Mar Pollut Bull 160:111649. https://doi.org/10.1016/j.marpo lbul.2020.111649

Islam ARMT, Siddiqua MT, Zahid A, Tasnim SS, Rahman MM (2020a) Drinking appraisal of coastal groundwater in Bangladesh: an approach of multi-hazards towards water security and health safety. Chemosphere 255:126933

Islam ARMT, Islam HT, Mia MU, Khan R, Habib MA, BodrudDoza $M$ et al (2020b) Co-distribution, possible origins, status and potential health risk of trace elements in surface water sources from six major river basins, Bangladesh. Chemosphere 249:126180

Islam MS, Idris AM, Islam ARMT, Ali MM, Rakib MRJ (2021) Hydrological distribution of physicochemical parameters and heavy metals in surface water and their ecotoxicological implications in the bay of Bengal coast of Bangladesh. Environ Sci Poll Res:1-15

Islam MS, Kormoker T, Mazumder M, et al. (2021a) Trace elements concentration in soil and plant within the vicinity of abandoned tanning sites in Bangladesh: an integrated chemometric approach for health risk assessment. Toxin Rev 0:1-16. https://doi.org/10. 1080/15569543.2021.1925919

Islam MS, Kormoker T, Idris AM, Proshad R, Kabir MH (2021b) Plant-microbe-metal interactions for heavy metal bioremediation: a review. Crop Pasture Sci DOI. https://doi.org/10.1071/CP21322

Jomova K, Jenisova Z, Feszterova M et al (2011) Arsenic: toxicity, oxidative stress and human disease. J Appl Toxicol 31:95-107

Kabir MM, Akter S, Ahmed FT, Mohinuzzaman M, Didar-ul-Alam M, Mostofa KM, Islam ARMT (2021) Salinity-induced fluorescence 
dissolved organic matter influence co-contamination, quality and risk to human health of tube well water in southeast coastal Bangladesh. Chemosphere 275:130053

Khan M A, Castro-Guerrero N A, Mendoza C, ozatl D (2014) Moving toward a precise nutrition: preferential loading of seeds with essential nutrients over non-essential toxic elements. Front Plant Sci 5: 51

Kibria G, Hossain MM, Mallick D, Lau TC, Wu R (2016) Monitoring of metal pollution in waterways across Bangladesh and ecological and public health implications of pollution. Chemosphere 165:1-9

Kormoker T, Proshad R, Islam MS, Shamsuzzoha M, Akter A, Tusher TR (2020) Concentrations, source apportionment and potential health risk of toxic metals in foodstuffs of Bangladesh. Toxin Rev:1-14

Kumar S, Prasad S, Yadav KK et al (2019) Hazardous heavy metals contamination of vegetables and food chain: role of sustainable remediation approaches - a review. Environ Res 179:108792

Lai CH, Lin CH, Liao CC, Chuang KY, Peng YP (2018) Effects of heavy metals on health risk and characteristic in surrounding atmosphere of tire manufacturing plant, Taiwan. RSC Adv 8:3041-3050

Li H, Dong X, da Silva EB, de Oliveira LM, Chen Y, Ma LQ (2017) Mechanisms of metal sorption by biochars: biochar characteristics and modifications. Chemosphere 178:466-478

Li HB, Li MY, Zhao D, Li J, Li SW, Xiang P, Ma Q (2020a) Arsenic, lead, and cadmium bioaccessibility in contaminated soils: measurements and validations. Critic Rev Environ Sci Technol 50(13):1303-1338

Li J, Wang G, Liu F, Cui L, Jiao Y (2020b) Source apportionment and ecological-health risks assessment of heavy metals in topsoil near a factory, Central China. Exp Health 1:1-4

Mansoor S, Kour N, Manhas S, Zahid S et al (2020) Biochar as a tool for effective management of drought and heavy metal toxicity. Chemosphere 129458

Mari M, Rovira J, Sánchez-Soberón F, Nadal M, Schuhmacher M, Domingo JL (2018) Partial replacement of fossil fuels in a cement plant: assessment of human health risks by metals, metalloids and PCDD/fs. Environ Res 174:188-194

Maruf MA, Punom NJ, Saha B, Moniruzzaman M, Suchi PD, Eshik MM, Rahman MS (2021) Assessment of human health risks associated with heavy metals accumulation in the freshwater fish Pangasianodon hypophthalmus in Bangladesh. Exp Health 11:1-23

McArthur JM, Ghosal U, Sikdar PK, Ball JD (2016) Arsenic in groundwater: the deep Late Pleistocene aquifers of the Western Bengal Basin. Environ Sci Technol 50:3469-3476

Mihajlov I, Mozumder MRH, Bostick BC, et al. (2020) Arsenic contamination of Bangladesh aquifers exacerbated by clay layers Nat Commun 11:. https://doi.org/10.1038/s41467-020-16104-z

Mortuza MG, Al-Misned FA (2015) Heavy metal concentration in two freshwater fishes from Wadi Hanifah (Riyadh, Saudi Arabia) and evaluation of possible health hazard to consumers. Pak J Zool 47:839-845

Mottalib MA, Somoal SH, Aftab M, Shaikh A, Islam MS (2016) Heavy metal concentrations in contaminated soil and vegetables of tannery area in Dhaka, Bangladesh. Int J Curr Res 8:30369-30373

Muthusaravanan S et al (2018) Phytoremediation of heavy metals: mechanisms, methods and enhancements. Environ Chem Lett 16(4):1339-1359

Naser HM, Rahman MZ, Sultana S, Quddus MA, Hossain MA (2018) Heavy metal accumulation in leafy vegetables grown in industrial areas under varying levels of pollution. Bangladesh. J Agric Res 43:39-51
Nasir AM, Goh PS, Abdullah MS, Ng BC, Ismail AF (2019) Adsorptive nanocomposite membranes for heavy metal remediation: recent progresses and challenges. Chemosphere 232:96-112

Pourang N, Noori AS (2012) Assessment of metals in fourteen species of vegetables and crops cultivated in a suburban area using multivariate analysis. Toxicol. Environ Chem 94:694-712

Proshad R, Kormoker T, Islam MS, Chandra K (2020) Potential health risk of heavy metals via consumption of rice and vegetables grown in the industrial areas of Bangladesh. Human Eco Risk Assess 26(4):921-943

Qin G, Niu Z, Yu J, Li Z, Ma JY, Xiang P (2020) Soil heavy metal pollution and food safety in China: effects, sources and removing technology. Chemosphere 129205

Rahman Z (2020) An overview on heavy metal resistant microorganisms for simultaneous treatment of multiple chemical pollutants at co-contaminated sites, and their multipurpose application. J Hazard Mater 396:122682

Rahman MS, Molla AH, Saha N et al (2012a) Study on heavy metals levels and its risk assessment in some edible fishes from Bangshi River, Savar, Dhaka, Bangladesh. Food Chem 134(4):1847-1854

Rahman SH, Khanam D, Adyel TM, Islam MS, Ahsan MA, Akbor MA (2012b) Assessment of heavy metal contamination of agricultural soil around Dhaka export processing zone (DEPZ), Bangladesh: implication of seasonal variation and indices. Appl Sci 2:584-601

Rahman MA, Rahman A, Khan MZK, Renzaho AMN (2018) Human health risks and socio-economic perspectives of arsenic exposure in Bangladesh: a scoping review. Ecotoxicol Environ Saf 150:335-343. https://doi.org/10.1016/j.ecoenv.2017.12.032

Rahman MS, Jolly YN, Akter S, Kamal NA, Rahman R, Choudhury TR, Begum BA (2021a) Sources of toxic elements in indoor dust sample at export processing zone (EPZ) area: Dhaka, Bangladesh; and their impact on human health Environ Sci Pollu Res $1-18$

Rahman MS, Kumar S, Nasiruddin M, Saha N (2021b) Deciphering the origin of $\mathrm{cu}, \mathrm{Pb}$ and $\mathrm{Zn}$ contamination in school dust and soil of Dhaka, a megacity in Bangladesh. Environ Sci Pollu Res 1-16

Rakib MRJ, Hossain MB, Jolly YN, Akther S, Islam S (2021a) EDXRF detection of trace elements in salt marsh sediment of Bangladesh and probabilistic ecological risk assessment. Soil Sediment Contam: An Int J 1-20

Rakib MRJ, Jolly YN, Begum BA, Choudhury TR, Fatema KJ, Islam MS, Idris AM (2021b) Assessment of trace element toxicity in surface water of a fish breeding river in Bangladesh: a novel approach for ecological and health risk evaluation. Toxin Rev:1-17

Rakib MRJ, Jolly YN, Enyoh CE, Khandaker MU, Hossain MB, Shirin A, Alsubaie A, Abdulraheem Almalki SA, Bradley DA (2021c) Levels and health risk assessment of heavy metals in dried fish consumed in Bangladesh. Sci Rep 11:14642. https://doi.org/10. 1038/s41598-021-93989-w

Ratul AK, Hassan M, Uddin MK, Sultana MS, Akbor MA, Ahsan MA (2018) Potential health risk of heavy metals accumulation in vegetables irrigated with polluted river water. Int Food Res J 25:329-338

Rehman K, Fatima F, Waheed I, Akash MSH (2018) Prevalence of exposure of heavy metals and their impact on health consequences. J Cell Biochem 119:157-184

Ren Y, Luo Q, Zhuo S, Hu Y, Shen G, Cheng H, Tao S (2021) Bioaccessibility and public health risk of heavy metal (loid) $\mathrm{s}$ in the airborne particulate matter of four cities in northern China. Chemosphere 277:130312

Renu K, Chakraborty R, Haritha M, et al. (2021) Molecular mechanism of heavy metals (lead, chromium, arsenic, mercury, nickel 
and cadmium) induced hepatotoxicity-a review. Chemosphere 129735

Saha N, Rahman MS, Jolly YN, Rahman A, Sattar MA, Hai MA (2016) Spatial distribution and contamination assessment of six heavy metals in soils and their transfer into mature tobacco plants in Kushtia District, Bangladesh. Environ Sci Pollu Res 23(4):3414-3426

Saha N, Bodrud-Doza M, Islam AT, Begum BA, Rahman MS (2020) Hydrogeochemical evolution of shallow and deeper aquifers in Central Bangladesh: arsenic mobilization process and health risk implications from the potable use of groundwater. Environ Earth Sci 79(20):1-18

Sarker MS, Quadir QF, Zakir HM, Nazneen T, Rahman A (2017) Evaluation of commonly used fertilizers, fish and poultry feeds as potential sources of heavy metals contamination in food. Asian Aus J Food Safe Sec 1(1):74-81

Shaheen N, Irfan NM, Khan IN, Islam S, Islam MS, Ahmed MK (2016) Presence of heavy metals in fruits and vegetables: health risk implications in Bangladesh. Chemosphere 152:431-438

Shamsudduha M, Joseph G, Haque SS, Khan MR, Zahid A, Ahmed KM (2019) Multi-hazard groundwater risks to water supply from shallow depths: challenges to achieving the sustainable development goals in Bangladesh. Exp Health 15:1-4

Sharmin S, Mia J, Miah MS, Zakir HM (2020) Hydrogeochemistry and heavy metal contamination in groundwaters of Dhaka metropolitan city, Bangladesh: assessment of human health impact. Hydro Res 3:106-117

Singh R, Venkatesh AS, Syed TH, Reddy AGS, Kumar M, Kurakalva RM (2017) Assessment of potentially toxic trace elements contamination in groundwater resources of the coal mining area of the Korba coalfield, Central India. Environ Earth Sci 76(16):1-17

Skoczynska A, Skoczynska M, Turczyn B, Wojakowska A, Gruszczynski L, Scieszka M (2021) Exposure to arsenic in the air and 15-F2t-isoprostane in urine in a sub-population of inhabitants of a copper smelter region. Exp Health 19:1-6

Subhavana KL, Keerthana RT, Qureshi A (2020) Mercury in marine, freshwater and aquaculture species from South India and human exposure risk assessment. Exp Health 13:1-7

Tasrina RC, Rowshon A, Mustafizur AMR, Rafiqul I, Ali MP (2015) Heavy metals contamination in vegetables and its growing soil. J Environ Anal Chem 2(142):2

Tusher TR, Sarker ME, Nasrin S, Kormoker T, Proshad R, Islam MS, Mamun S, Al Tareq ARM (2020) Contamination of toxic metals and polycyclic aromatic hydrocarbons (PAHs) in rooftop vegetables and human health risks in Bangladesh. Toxin Rev:1-16. https://doi.org/10.1080/15569543.2020.1767650
WHO (2004) World Health Organization, guidelines for drinkingwater quality: recommendations, third ed., vol. $13-524$. Geneva, Switzerland. https://www.who.int/water_sanitation_health/dwq/ GDWQ2004web.pdf. Accessed 20 June 2021

WHO (2017) World Health Organization. Guidelines for drinkingwater quality: first addendum to the fourth edition. Available online: https://apps.who.int/iris/bitstream/handle/10665/254636/ 9789241550017-eng.pdf. Accessed 10 July 2021

Yarsan E, Yipel M (2013) The important terms of marine pollution "biomarkers and biomonitoring, bioaccumulation, bioconcentration, biomagnification". J Mol Biomark Diagn S1:003

Yin K, Wang Q, Lv M, Chen L (2019) Microorganism remediation strategies towards heavy metals. Chem Eng J 360:1553-1563

Yuvaraj A, Thangaraj R, Karmegam N, Ravindran B, Chang SW, Awasthi M K, Kannan S (2021) Activation of biochar through exoenzymes prompted by earthworms for vermibiochar production: a viable resource recovery option for heavy metal contaminated soils and water Chemosphere 130458

Zafarzadeh A, Rahimzadeh H, Mahvi AH (2018) Health risk assessment of heavy metals in vegetables in an endemic esophageal cancer region in Iran. Health Scope 7:e12340

Zakir HM, Sumi SA, Sharmin S, Mohiuddin KM, Kaysar S (2015) Heavy metal contamination in surface soils of some industrial areas of Gazipur, Bangladesh. J Chem Biol Phys Sci 5:2191-2206

Zakir HM, Quadir QF, Mollah MZI (2020a) Human health risk assessment of heavy metals through the consumption of common foodstuffs collected from two divisional cities of Bangladesh Exp Health 0123456789

Zakir HM, Sharmin S, Akter A, Rahman MS (2020b) Assessment of health risk of heavy metals and water quality indices for irrigation and drinking suitability of waters: a case study of Jamalpur Sadar area, Bangladesh. Environ Adv 2:100005

Zhou T, Zhao M, Zhao X, Guo Y, Zhao Y (2021) Simultaneous remediation and fertility improvement of heavy metals contaminated soil by a novel composite hydrogel synthesized from food waste. Chemosphere 275:129984

Publisher's note Springer Nature remains neutral with regard to jurisdictional claims in published maps and institutional affiliations. 